\section{Plato's Theory of Education}

By Prof. R. C. Lodge. With an Appendix on The Education of Women According to Plato, by Rabbi Solomon Frank. (International Library of Sociology and Social Reconstruction.) Pp. viii + 322. (London: Kegan Paul and Co., Ltd., 1947.) 18s. net.

7 HE aim of this important book, by Prof. R. C.

Lodge, of the University of Manitoba, is to meet the needs of students of educational theory, "of those who are interested in Plato as thinker and who find in him a standing challenge to their own powers of thought, and of that wider group who are seeking to enlarge their own vision". The author considers Plato as writer, teacher, and thinker who believed that in the balanced philosophic life is to be found the solution of all human problems. Prof. Lodge fulfils his promise in twelve admirably written chapters. Turn where you will in these chapters, and you are struck by their freshness, clearness and vitality. He writes as a scholar, but not for scholars only.

As to the bibliography, a British reader naturally expects to find certain names, and he does find the names of Nettleship and A. E. Taylor. But he wonders why no mention is made of Bermard Bosanquet, the distinguished author of "A Companion to Plato's Republic" and of "The Education of the Young in the Republic of Plato", published in 1900. There was good reason for omitting R. H. S. Crossman's "Plato Today" (1937), which is too exclusively British in its outlook to attract an American writer. Some of the British books mentioned by Prof. Lodge, though important in their own way, contain only bare references to Plato. For this there may be good reasons; but their inclusion looks rather odd.

\section{Mechanics}

By Prof. John C. Slater and Prof. Nathaniel H. Frank. (International Series in Pure and Applied Physics.) Pp. xiii +297 . (New York and London : MeGraw-Hill Book Co., Inc., 1947.) $20 s$.

THE word 'mechanics', although derived from $1 \mu \eta \chi \alpha \nu \eta$, a machine or contrivance, is often used to describe the general treatment of natural philosophy by mathematical methods, and it is in this sense that the authors here employ it. This particular work is the first of several, which are intended. to replace their "Introduction to Theoretical Physics", published in 1933, and is presumably to be followed by others on electromagnetism and quantum theory. In this dissection, it is believed that a better treat. ment of each field can be provided, at the same time preserving the general unity essential both to teacher and student.

The main emphasis here is on dynamics and the theory of vibrations, and the first seven chapters are devoted to the classical development of this theory. After the enunciation of Newton's laws of motion the fundamental principles of particle and rigid dynamics are deduced, to be followed by the methods of Euler, Lagrange and, finally, Hamilton. Special vibration problems are then considered, such as those of a string, a membrane, and an elastic solid, and the last chapter is concerned with the elements of irrotational fluid flow. A number of appendixes are also provided to elucidate the properties of complex numbers, vectors, tensors, Fourier series and Bessel functions, which have been previously utilized in the main text.

The whole work is beautifully bound and clearly printed on good quality paper, and should prove a useful book of reference.

\section{Die Bluteiweisskörper des Menschen}

Untersuchungsmethoden und deren klinisch-praktische Bedeutung. Von Dr. F. Wuhrmann und Dr. Ch. Wunderly. Pp. 354. (Basel : Benno Schwabe und Co., 1947.) 36 Swiss francs.

THIS book is divided into three parts, of which the first deals with the general physico-chemical properties of serum proteins. The second chapter considers methods used in the study of serum proteins : electrophoresis, ultracentrifugation, colour tests such as the Millon reaction, and finally a series of empirical clinical methods such as the Takata reaction, among them some not in use in Britain. In the third part an account is given of the changes occurring in diseases as revealed by the methods described previously. The fourth chapter groups diseases according to the serum fraction mainly affected by them. The concluding chapters sketch the formation of blood proteins (13 pages) and the therapeutic application of serum fractions (17 pages).

A work such as this, written by five authors, will necessarily show some unevenness; but by more severe editing, some repetitions might have been prevented. In the pathological sections, English literature is not sufficiently taken into account. In the chapter on nephrosis, for example (p. 281), out of fifty references, only one is to an American publication, and there is not one to a British journal. In spite of these shortcomings, the book contains much valuable information and will enable workers in this field to get an insight into the trends of research in Switzerland.

\section{Recent Advances in Endocrinology}

By Prof. A. T. Cameron. Sixth edition. Pp. vii +443. (London: J. and A. Churchill, Ltd., 1947.) $21 s$.

$\mathrm{N}^{\prime}$ form, this sixth edition does not differ from its 1 predecessor, which was published in 1945, and the revisions it incorporates are in general only slight. The more important additions are paragraphs on the treatment of hyperthyroidism with thiouracil, and on the iodoproteins; further information about the effects of adrenalectomy and the treatment of Addison's disease; and some interesting new facts about the parathyroids. The book is a very useful summary of the whole field of hormone studies, and it is bound to enjoy the success of previous editions.

\section{Exploring Our National Parks and Monuments}

By Devereux Butcher. (Published under the auspices of the National Parks Association.) Pp. 160. (New York and London: Oxford University Press, 1947.) 15s. net.

7 HE United States have long given a lead to the 1 world in the matter of national parks. Although the Yellowstone Park is world-famous, it is but one of their many Nature reserves, embracing some twelve million acres of land, lake and forest. There are reserves from Maine to California and from Alaska to Florida. This book by the executive secretary and editor of the National Parks Association of America is a guide to their twenty-four national parks and thirty-eight Nature monuments. It gives a description of each reserve, its scenery and fauna; also how to reach it and the accommodation avail. able for visitors. The many photographic illustrations are excellent and more than tantalizing for the Eng. lish reader, whose travel opportunities are now so restricted. The book is well produced and admirably fulfils its object.
Frances PitT 